\title{
Comparative Evaluation of Colemanite and Sodium Pentaborate as Boron Sources for Rice Grown in Flooded Calcareous Soil
}

\author{
Muhammad Saleem Sarki ${ }^{1}$, Khanif Y. M. ${ }^{1}$, Fauziah C. I. ${ }^{1}$, Samsuri A. W. ${ }^{1} \&$ Hafeez B. ${ }^{1}$ \\ ${ }^{1}$ Department of Land Management, Faculty of Agriculture, University of Putra Malaysia, Selangor, Malaysia \\ Correspondence: Muhammad Saleem Sarki, Department of Land Management, Faculty of Agriculture, \\ University of Putra Malaysia, Selangor, Malaysia. E-mail: sarkisaleem@yahoo.com
}

Received: July 25, 2012 Accepted: November 22, 2012 Online Published: February 25, 2013

doi:10.5539/sar.v2n2p134

URL: http://dx.doi.org/10.5539/sar.v2n2p134

\begin{abstract}
Boron insufficiency in the agricultural soils is common and wide spread problem in many regions of the world. The effectiveness of crushed ore colemanite as B sources for rice crop under flooded calcareous soil were evaluated in a glass house study. We studied the effects of powder colemanite (PC) and granular colemanite (GC) in comparison with the refined sodium pentaborate fertilizer at the rates of $0,1,2$, and $3 \mathrm{~kg} \mathrm{~B} \mathrm{ha}^{-1}$ on growth and yield parameters of rice crop as well as the true control $\left(0 \mathrm{~kg} \mathrm{~B} \mathrm{ha}^{-1}\right)$. Sodium pentaborate (SP) and (PC) application of 2 and $3 \mathrm{~kg} \mathrm{~B} \mathrm{ha}^{-1}$ significantly increased the plant height, number of tillers and panicles per plant, number of grains per panicle, weight of 1000 grains and $\mathrm{B}$ concentration in grain compared the 0 and $1 \mathrm{~kg} \mathrm{~B} \mathrm{ha}^{-1}$. Rice crop with SP and PC applied at $3 \mathrm{~kg} \mathrm{~B} \mathrm{ha}^{-1}$ produced significantly (18\% over the control) higher grain yield than the $0 \mathrm{~kg} \mathrm{~B} \mathrm{ha}^{-1}$ treatment. Pots fertilized with SP and PC produced similar results as grain yield difference between them was not significant so these B fertilizers were very effective in supplying B to rice crop, but GC applied pots produced significantly low yield because of its bigger particle size, due to which B was not released from fertilizer. This study proved that colemanite with smaller particle size is an effective B source and it is cheaper than refined products so it should be applied for harvesting higher yields.
\end{abstract}

Keywords: boron, rice, sodium pentaborate, colemanite

\section{Introduction}

Rice (oryza sativa) occupies a position of over whelming importance in the global food system. It belongs to the Gramineae grass family and is a vital food crop because half the world population eats rice as a main part of their daily diets. Besides being used as a staple food rice is also used in industries as a raw material. It is used in starch, brewing, hard board, soap and paper industries. Rice straw and husk are used as cattle and poultry feed "Benton, 2003 ". About $80 \%$ of the harvested rice area and $92 \%$ of the total global production is from irrigated and lowland rainfed rice systems (Dobberman, 2000). To meet the demand of increasing population, rice yields must increase by $25 \%$ over the next 20 years (IRRI, 2008). Fertilizer uses in rice mostly relate to macro nutrients thus one main cause of low rice production is imbalanced nutrient application (Rashid, 2002). Micronutrient deficit is one of the major reasons of the decreasing production trends in rice growing countries (Mohanty, 2009).

Boron is important for various plant physiological functions such as nucleic acid, carbohydrate, protein, indole acetic acid and phenol metabolism, cell wall synthesis and structure, membrane integrity and function, sugar translocation (Goldbach, 2001). Boron deficiencies occur over a much wider range of soils and crops in comparison to deficiencies of any other micronutrient elements (Yan, 2006). There are two types of B fertilizer sources, the refined completely soluble materials which can be conveniently applied either in solution or as solids, and the crushed ores which have variable chemical and physical properties (Bell, 2008). The refined products are Sodium tetra borate, $\left(\mathrm{Na}_{2} \mathrm{~B}_{4} \mathrm{O}_{7} \cdot 5 \mathrm{H}_{2} \mathrm{O}\right)$ borax $\left(\mathrm{Na}_{2} \mathrm{~B}_{4} \mathrm{O}_{7} \cdot 10 \mathrm{H}_{2} \mathrm{O}\right)$, sodium pentaborate $\left(\mathrm{Na}_{2} \mathrm{~B}_{10} \mathrm{O}_{16} \cdot 10 \mathrm{H}_{2} \mathrm{O}\right)$, solubor $\left(\mathrm{Na}_{2} \mathrm{~B}_{8} \mathrm{O}_{13} \cdot 4 \mathrm{H}_{2} \mathrm{O}\right)$ and boric acid $\left(\mathrm{H}_{3} \mathrm{BO}_{3}\right)$. The crushed ores are colemanite $\left(\mathrm{Ca}_{2} \mathrm{~B}_{6} \mathrm{O}_{11} \cdot 5 \mathrm{H}_{2} \mathrm{O}\right)$, ulexite $\left(\mathrm{Na}_{2} \mathrm{O} \cdot 2 \mathrm{CaO} .5 \mathrm{~B}_{2} \mathrm{O}_{3} \cdot 16 \mathrm{H}_{2} \mathrm{O}\right)$, datolite $\left(2 \mathrm{CaO} \cdot \mathrm{B}_{2} \mathrm{O}_{3} \cdot 2 \mathrm{SiO}_{2} \cdot \mathrm{H}_{2} \mathrm{O}\right)$, hydroboracite $\left(\mathrm{CaO} . \mathrm{MgO} \cdot 3 \mathrm{~B}_{2} \mathrm{O}_{3} \cdot 6 \mathrm{H}_{2} \mathrm{O}\right)$ and ascharite $\left(2 \mathrm{MgO} \cdot \mathrm{B}_{2} \mathrm{O}_{3} \cdot \mathrm{H}_{2} \mathrm{O}\right)$. Sodium pentaborates $\mathrm{SP}$ and boric acid are readily dissolved in soils and are rapidly accessible for plant uptake, but at the same time $\mathrm{B}$ can be leached from the soil root zone. Only the two crushed ores ulexite and colemanite are only used for soil application (Bell, 2008). Boron can be satisfactorily applied to the soil to provide season long B supply for a crop.

Crushed ore colemanite is a cheap and slow release source of B in comparison to refined products but this B 
source is not widely used as fertilizer. Byers et al. (2001) conducted a greenhouse study on alfalfa to evaluate the effectiveness of four B fertilizers (Granubor, Hydroboracite, Ulexite and Colemanite). He reported that in the first cutting there was difference in B sources. However by the third and fourth cuttings, there was no significant difference among the four fertilizer sources. Very few comparative studies between refined products and crushed ores on crops have been reported. Most experiments on ores have been conducted in pots to study toxicity and leaching rather than effect on crop (Shorrocks, 1997). The objective of this study was to comparatively evaluate the efficacy of refined B product sodium pentaborate and crushed borate ore colemanite as sources of B for rice under flooded calcareous soil condition.

\section{Materials and Methods}

\subsection{Soil Analysis}

A pot experiment was conducted in the glass house of University Putra Malaysia during main season of 2009. The calcareous soil used was collected from Perlis, Malaysia, because calcareous paddy soils are only present in this region of Malaysia and laboratory analysis of soil samples showed that these were deficient in plant available B. Boron in the soil samples was analyzed by hot water extraction method (Bingham, 1982) and in the plant tissue it was determined by the dry ashing followed by azomethine-H colorimetric method (Benton, 2001). Soil $\mathrm{pH}$ was measured in soil; water $(1: 2.5)$ extract using PHM210 Standard $\mathrm{pH}$ meter at $30^{\circ} \mathrm{C}$ (Benton, 2001). Phosphorus was extracted using Bray and Kurtz \#2 extractants (Bray \& Kurtz, 1945). The Carbon Analyzer were used to analyze the organic carbon of samples (Benton, 2001). Soil texture, total $\mathrm{N}$ and cation exchange capacity (CEC) were determined using the pipette method (Gee \& Bauder, 1986), Kjeldahl digestion method (Bremner \& Mulvane, 1982) and leaching method (Thomas, 1982), respectively.

\subsection{Rice Sowing}

Healthy seeds of variety MR220 were selected for planting. These seeds were soaked in a beaker with water for 24 hours and then placed on soaked filter paper in Petri dishes for 48 hours for pre germination. When the radicle emerged in the third day, the seeds were sown into pots. The number of seeds needed per pot was calculated on the basis of surface area of pot at sowing rate of $140 \mathrm{~kg} \mathrm{ha}^{-1}$. Water level in the pots was retained at $5 \mathrm{~cm}$ above the soil surface.

\subsection{Fertilizer Sources and Rates}

Experiment was conducted by adding $6 \mathrm{~kg}$ soil into each plastic pot. Each pot received either sodium pentaborate SP, powder colemanite (PC) with particle size $75 \mu \mathrm{m}$ or granular colemanite (GC) particle size $0.3 \mathrm{~mm}$ and the rates were $0 \mathrm{~kg} \mathrm{~B} \mathrm{ha}^{-1}, 1 \mathrm{~kg} \mathrm{~B} \mathrm{ha}{ }^{-1}, 2 \mathrm{~kg} \mathrm{~B} \mathrm{ha}^{-1}$ and $3 \mathrm{~kg} \mathrm{~B} \mathrm{ha}^{-1}$. These B sources were compared with each other at different $\mathrm{B}$ rates as well as the true control $\left(0 \mathrm{~kg} \mathrm{~B} \mathrm{~h}^{-1}\right)$. The fertilizer was applied at the time of planting by surface application. Macronutrients were also applied according to the rates-recommended by Malaysian Agriculture Development Authority, a government owned research organization. Nitrogen was applied as urea at the rate of $140 \mathrm{~kg} \mathrm{~N} \mathrm{ha}^{-1}$ in three split doses at 15, 40 and 60 days after planting while $\mathrm{P}$ and $\mathrm{K}$ were both applied after 15 days of planting at the rate of $70 \mathrm{~kg}\left(\mathrm{P}_{2} \mathrm{O}_{5}\right.$ or $\left.\mathrm{K}_{2} \mathrm{O}\right) \mathrm{ha}^{-1}$ in the form of triple super phosphate and muriate of potash, respectively. Pots were kept in randomized complete block design (RCBD) with three replications.

\subsection{Crop and Soil Parameters}

The recorded crop parameters were number of tillers and panicles per plant, plant and panicle height, fresh and dry weight of straw with and without grain, weight of panicle, grains per panicle, empty grains per panicle, grain weight from each pot, weight of 1000 grains, chlorophyll content of leaf (measured with a SPAD meter), and B concentration in plant straw and grain. Tillers and panicles were counted at maturity stage; at the time of harvest plant height and seed yield were measured. Panicles were harvested and threshed by hand. The filled grains were separated from unfilled ones by using salt solution of 1.06 specific gravity (Seizo, 1980). The 20 grams representative grain and straw samples were ground to pass through a $1 \mathrm{~mm}$ sieve and were kept in plastic containers for chemical analysis.

\subsection{Statistical Analysis}

The data were analyzed using Statistical Analysis System (SAS) software package version 8.2 and mean comparisons between treatments were determined using analysis of variance (ANOVA) procedure and Tukeys' Honestly Significant Difference at 95\% level of confidence. 


\section{Results and Discussion}

\subsection{Soil of Experiment}

The calcareous soil used in this experiment belongs to Bukit Temiang series and classified as a Typic Hapludult under the USDA Soil Taxonomy classification (Paramananthan, 2000). The soil was deficient in B $\left(0.32 \mathrm{mg} \mathrm{kg}^{-1}\right)$ with high $\mathrm{pH}$ (8.1). Soil textural class was silty clay with $2 \%$ organic carbon, $9.1 \mathrm{cmol} \mathrm{kg}^{-1} \mathrm{CEC}, 20 \mathrm{mg} \mathrm{kg}^{-1}$ phosphorus and $0.16 \%$ total nitrogen.

\subsection{Effects of B Fertilizer Rates and Sources on Rice Yield and Growth Parameters}

\subsubsection{Number of Panicles per Plant}

Boron fertilizers SP, PC and GC application on rice crop increased the production of panicles plant ${ }^{-1}$ (Table1). Boron sources SP and PC significantly increased the number of panicles per plant and there was no significant difference in number of panicles per plant between SP and PC applied pots. Although the pots treated with GC also increased the number of panicles but the numbers were significantly low than the SP and PC. The interaction between fertilizers and $\mathrm{B}$ rates was significant.

The results further indicated that application of 2 and $3 \mathrm{~kg} \mathrm{~B}^{-1}$ produced the higher number of panicles compared to the control and the $1 \mathrm{~kg} \mathrm{~B} \mathrm{ha}^{-1}$ rate. However, there was no significant difference in panicles per plant between 2 and $3 \mathrm{~kg} \mathrm{~B} \mathrm{ha}^{-1}$. Sodium pentaborate and PC applied pots produced more panicles because B from these fertilizers was readily available for plant uptake, and on the other hand GC solubility was low due to its larger particle size. This increase in the number of panicles was due to the role of B in the reproduction of plants and germination of pollen as B promotes pollen tube growth (Bolanos et al., 2004). Sodium pentaborate and PC had shown similar pattern of B release for plant uptake as was observed in the field experiments (M. Saleem et al., 2011). Our results are consistent with the results of (Ashraf et al., 2004) which reported that with B application, the number of productive tillers and panicle per hill of rice plant increased.

Table 1. Effect of B fertilizer rates and sources on number of panicles per plant

\begin{tabular}{ccccc}
\hline B levels kg ha $^{-1}$ & SP & $\begin{array}{c}\text { PC } \\
\text { Panicles }\end{array}$ & GC & Mean of B levels \\
\hline 0 & $2.1 \mathrm{c}$ & $2.1 \mathrm{~d}$ & $2.1 \mathrm{~b}$ & $2.1 \mathrm{~B}$ \\
1 & $2.8 \mathrm{~b}$ & $2.6 \mathrm{c}$ & $2.1 \mathrm{~b}$ & $2.4 \mathrm{~B}$ \\
2 & $3.4 \mathrm{a}$ & $3.3 \mathrm{~b}$ & $2.5 \mathrm{a}$ & $3.0 \mathrm{~A}$ \\
3 & $4.0 \mathrm{a}$ & $3.9 \mathrm{a}$ & $3.0 \mathrm{a}$ & $3.7 \mathrm{~A}$ \\
Mean of B source & $3.1 \mathrm{~A}$ & $2.9 \mathrm{~A}$ & $2.4 \mathrm{~B}$ & \\
\hline
\end{tabular}

The values with same uppercase letter within columns and rows and the values with same lowercase letter within $\mathrm{B}$ source at different levels are not significantly different at $\mathrm{p}=0.05 . \mathrm{SP}=$ Sodium pentaborate, $\mathrm{PC}=$ Powder Colemanite and $\mathrm{GC}=$ Granular Colemanite.

\subsubsection{Percentage of Empty Grains}

The results of SP, PC and GC application on the percentage of non-ripened grains per panicle is shown in Table 2. Comparison of means of empty grains for different fertilizers showed that the difference between SP and PC was not significant but plants applied with both B sources had significantly lower percentage of empty grains than plants applied with GC. Under calcareous soil conditions, SP and PC were found to be ineffective as a B source, similar the results observed in acidic soils (Saleem et al., 2011).

Boron application at $3 \mathrm{~kg} \mathrm{~B} \mathrm{ha}^{-1}$ significantly lowered the percentage of empty grains compared to the other $\mathrm{B}$ levels. Application of $2 \mathrm{~kg} \mathrm{~B} \mathrm{ha}^{-1}$ significantly decreased the non-ripened or non-fertilized grains in comparison to 0 and $1 \mathrm{~kg} \mathrm{~B} \mathrm{ha}^{-1}$ and the control. This decrease in unfilled spikelets was pragmatic because B hinders the abortion of the ovaries, produce functional flowers and its insufficiency can cause the sterility of pollen (O'Niell et al., 2004). Boron application decreased the plant empty grains because it is required for development of reproductive tissues and deficiency can cause male sterility and floral abnormalities which result in low grain set and poor seed quality (Dell \& Bell, 2002). Ehsan et al. (2009) reported that B fertilization improved rice tillering capacity, weight of grain, seed setting and decreased empty grains. 
Table 2. Effect of B fertilizer rates and sources on percentage of empty grains per panicles

\begin{tabular}{ccccc}
\hline B levels kg ha & SP & $\begin{array}{c}\text { PC } \\
\%\end{array}$ & GC & Mean of B levels \\
\hline 0 & $22.4 \mathrm{a}$ & $22.4 \mathrm{a}$ & $22.4 \mathrm{a}$ & $22.4 \mathrm{~A}$ \\
1 & $21.0 \mathrm{a}$ & $21.5 \mathrm{a}$ & $21.0 \mathrm{a}$ & $21.3 \mathrm{~A}$ \\
2 & $18.0 \mathrm{~b}$ & $19.0 \mathrm{~b}$ & $19.0 \mathrm{~b}$ & $18.6 \mathrm{~B}$ \\
3 & $16.1 \mathrm{c}$ & $17.0 \mathrm{c}$ & $18.6 \mathrm{~b}$ & $17.2 \mathrm{C}$ \\
Mean of B source & $18.9 \mathrm{~B}$ & $19.6 \mathrm{~B}$ & $20.3 \mathrm{~A}$ & \\
\hline
\end{tabular}

The values with same uppercase letter within columns and rows and the values with same lowercase letter within $\mathrm{B}$ source at different levels are not significantly different at $\mathrm{p}=0.05 . \mathrm{SP}=$ Sodium pentaborate $\mathrm{PC}=\mathrm{Powder}$ Colemanite and $\mathrm{GC}=$ Granular Colemanite.

\subsubsection{Weight of 1000 Grains}

The effect of SP, PC and GC application on weight of grains is shown in (Table 3). There was no difference in the weight of 1000 grains between SP and PC applied pots but the 1000 grains values were significantly higher than the GC applied pots. Analysis of data showed that there was significant interaction between fertilizer sources and rates. As B has a role in many plant physiological functions, spikelet quality and weight were positively affected. Sodium pentaborate and PC applied plants produced heavier spikelets because of B availability due to the soluble nature of these two fertilizers.

The highest weight of 1000 grains was recorded at $3 \mathrm{~kg} \mathrm{~B} \mathrm{ha}^{-1}$ but there was no significant difference in the weight of 1000 grains for pots applied with 1 and $2 \mathrm{~kg} \mathrm{~B} \mathrm{ha}^{-1}$. However, weight of grains for any B applied pot was higher than the control. At $3 \mathrm{~kg} \mathrm{~B} \mathrm{ha}^{-1} \mathrm{SP}$ applied pot had higher weight of 1000 grains and at $2 \mathrm{~kg} \mathrm{~B} \mathrm{ha}^{-1} \mathrm{PC}$ applied plants had higher grain weight than the other two fertilizers. Boron is very essential in the flowering, fertilization and seed-setting process of plants so improvement in grain weight may be owing to its role in the synthesis of ethylene and flower buds (Dell \& Bell, 2002). These results are in agreement with the findings of (Aslam et al., 2002) who conducted a glass house experiment under saline and saline-sodic soils and reported that $\mathrm{B}$ application increased the weight of rice grain and decreased the spikelet sterility.

Table 3. Effect of $B$ fertilizer rates and sources on weight of 1000 rice grains

\begin{tabular}{ccccc}
\hline B levels kg ha & SP & $\begin{array}{c}\text { PC } \\
\text { Grams }\end{array}$ & GC & Mean of B levels \\
\hline 0 & $15.5 \mathrm{~b}$ & $15.5 \mathrm{~b}$ & $15.5 \mathrm{a}$ & $15.5 \mathrm{C}$ \\
1 & $17.0 \mathrm{~b}$ & $17.0 \mathrm{ab}$ & $16.1 \mathrm{a}$ & $16.9 \mathrm{~B}$ \\
2 & $17.4 \mathrm{a}$ & $17.7 \mathrm{a}$ & $17.0 \mathrm{a}$ & $17.3 \mathrm{~B}$ \\
3 & $19.4 \mathrm{a}$ & $19.2 \mathrm{a}$ & $17.1 \mathrm{a}$ & $18.5 \mathrm{~A}$ \\
Mean & $17.3 \mathrm{~A}$ & $17.5 \mathrm{~A}$ & $16.6 \mathrm{~A}$ & \\
\hline
\end{tabular}

The values with same uppercase letter within columns and rows and the values with same lowercase letter within $\mathrm{B}$ source at different levels are not significantly different at $\mathrm{p}=0.05 . \mathrm{SP}=$ Sodium pentaborate, $\mathrm{PC}=\mathrm{Powder}$ Colemanite and $\mathrm{GC}=$ Granular Colemanite

\subsubsection{Boron Concentration in Rice Straw and Grain}

Sodium pentaborate, PC and GC significantly affected B concentrations of rice grain and plant straw (Tables 4 and 5). There was no significant difference in grain B concentration between SP and PC applied pots but plants from both pots had higher grain B concentration than the GC applied pots. In the case of B concentration in plant straw similar trend was observed. The interaction between fertilizers and rates was significant. Plant B uptake is a passive process so its continuous supply is necessary for normal growth. Although B from SP was released quickly but its uptake was according to plant needs; on the other hand PC was slowly released and whatever B quantity was released with the passage of time, proved to be enough for plant growth. Therefore, at the end of 
plant life cycle, both fertilizers were at par with each other.

Chemical analyses of grain samples showed that the highest B concentrations were measured in $3 \mathrm{~kg} \mathrm{~B} \mathrm{ha}^{-1}$ applied plants compared to the other treatments. Boron application at $2 \mathrm{~kg} \mathrm{ha}^{-1}$ showed higher rice grain $\mathrm{B}$ concentration over the 0 and $1 \mathrm{~kg} \mathrm{~B} \mathrm{ha}^{-1}$. The data regarding $\mathrm{B}$ concentration in plant shoot dry matter showed the same trend as of the grain. The highest $\mathrm{B}$ concentration was measured in plants which received $3 \mathrm{~kg} \mathrm{~B} \mathrm{ha}^{-1}$ followed by $2 \mathrm{~kg} \mathrm{~B} \mathrm{ha}^{-1}$. Boron concentration in rice plant increased because $\mathrm{B}$ uptake is correlated with the concentration of $\mathrm{H}_{3} \mathrm{BO}_{3}$ (Tariq et al., 2005). These results are in agreement with the findings of (Rashid et al., 2007) and (Yang et al., 2000) they reported that B application increased the leaf and grain B concentration of rice plant.

Table 4. Effect of B rates and sources on B concentration of grain

\begin{tabular}{ccccc}
\hline B levels kg ha $^{-1}$ & SP & $\begin{array}{c}\text { PC } \\
\mathrm{mg} \mathrm{kg}^{-1}\end{array}$ & GC & Mean of B levels \\
\hline 0 & $6.0 \mathrm{c}$ & $6.0 \mathrm{~b}$ & $6.0 \mathrm{a}$ & $6.0 \mathrm{C}$ \\
1 & $7.6 \mathrm{bc}$ & $7.0 \mathrm{~b}$ & $6.0 \mathrm{a}$ & $6.8 \mathrm{C}$ \\
2 & $9.0 \mathrm{ba}$ & $8.4 \mathrm{a}$ & $6.7 \mathrm{a}$ & $8.0 \mathrm{~B}$ \\
3 & $10.9 \mathrm{a}$ & $10.0 \mathrm{a}$ & $7.3 \mathrm{a}$ & $9.4 \mathrm{~A}$ \\
Mean of B sources & $8.3 \mathrm{~A}$ & $7.9 \mathrm{~A}$ & $6.5 \mathrm{~B}$ & \\
\hline
\end{tabular}

The values with same uppercase letter within columns and rows and the values with same lowercase letter within $\mathrm{B}$ source at different levels are not significantly different at $\mathrm{p}=0.05 . \mathrm{SP}=$ Sodium pentaborate, $\mathrm{PC}=$ Powder Colemanite and $\mathrm{GC}=$ Granular Colemanite.

Table 5. Effect of B rates and sources on B concentration in plant straw

\begin{tabular}{ccccc}
\hline B levels kg ha & SP & $\begin{array}{c}\text { PC } \\
\mathrm{mg} \mathrm{kg}^{-1}\end{array}$ & GC & Mean of B levels \\
\hline 0 & $6.6 \mathrm{c}$ & $6.6 \mathrm{c}$ & $6.6 \mathrm{a}$ & $6.6 \mathrm{C}$ \\
1 & $9.0 \mathrm{~b}$ & $8.0 \mathrm{~b}$ & $6.6 \mathrm{a}$ & $7.8 \mathrm{C}$ \\
2 & $11.0 \mathrm{a}$ & $10.3 \mathrm{a}$ & $6.7 \mathrm{a}$ & $9.4 \mathrm{~B}$ \\
3 & $13.3 \mathrm{a}$ & $13.0 \mathrm{a}$ & $7.3 \mathrm{a}$ & $11.2 \mathrm{~A}$ \\
Mean of B sources & $9.9 \mathrm{~A}$ & $9.4 \mathrm{~A}$ & $6.8 \mathrm{~B}$ & \\
\hline
\end{tabular}

The values with same uppercase letter within columns and rows and the values with same lowercase letter within $\mathrm{B}$ source at different levels are not significantly different at $\mathrm{p}=0.05 . \mathrm{SP}=$ Sodium pentaborate, $\mathrm{PC}=\mathrm{Powder}$ Colemanite and $\mathrm{GC}=$ Granular Colemanite.

\subsubsection{Boron Recovery Efficiency and B Use Efficiency}

Boron recovery and use efficiency were also affected by the rate of $\mathrm{b}$ application. Sodium pentaborate applied pots had higher recovery percentage than the other B fertilizers sources PC and GC. Based on calculations it was observed that the quantity of B taken up by the crop or B recovery efficiency was rising with the increasing rate of B. The highest recovery efficiency was calculated from $3 \mathrm{~kg} \mathrm{~B} \mathrm{ha}^{-1}$ followed by $2 \mathrm{~kg} \mathrm{~B} \mathrm{ha}^{-1}$. The highest recovery efficiency percentage was $6.0 \%$ at $3 \mathrm{~kg} \mathrm{~B} \mathrm{ha}^{-1}$ SP. Boron utilization efficiency also showed the same trend. Agronomic efficiency in B use (AEB) was higher at $3 \mathrm{~kg} \mathrm{~B} \mathrm{ha}^{-1}$. Sodium pentaborate exhibited higher AEB than the PC and GC.

\subsubsection{Grain Yield of Rice}

Fertilization of rice plants using SP and PC as B sources had positive effects on all growth parameters of the crop so ultimately grain yield per pot increased significantly (Table 6). The sodium pentaborate and PC fertilized pots gave equivalent grain yield but these both had significantly higher yield than the GC. The interaction between fertilizers and rate was significant. Boron application at $1 \mathrm{~kg} \mathrm{ha}^{-1}$ as PC produced higher yield than the other 
fertilizers and at 2 and $3 \mathrm{~kg} \mathrm{~B} \mathrm{ha}^{-1} \mathrm{SP}$ produced higher grain yield than PC and GC. Sodium pentaborate is a highly soluble B source so it was readily available for plant uptake and showed significant effect on all growth parameters. Likewise, PC which has very small particles ( $75 \mu \mathrm{m}$ diameters) was equivalent to SP. It is apparent from this study that particle size had significant effect on B release from colemanite. The results of this glasshouse experiment are similar to the results of field experiments conducted on same fertilizers under acidic soil condition (Saleem et al., 2011). Our earlier study on B dissolution kinetics, showed that soil $\mathrm{pH}$ had no effect on solubility of SP, PC and GC fertilizers (Saleem, 2009).

Boron fertilizer application at $3 \mathrm{~kg} \mathrm{~B} \mathrm{ha}^{-1}$ rate increased $18 \%$ rice grain yield over the $0 \mathrm{~kg} \mathrm{~B} \mathrm{ha}^{-1}$. Boron application at the rate of $3 \mathrm{~kg} \mathrm{ha}^{-1}$ produced significantly higher yield than the other treatments. The yield of $2 \mathrm{~kg}$ $\mathrm{B} \mathrm{ha} \mathrm{C}^{-1}$ applied pots was significantly higher than $1 \mathrm{~kg} \mathrm{~B} \mathrm{ha}^{-1}$ but there was no significant difference between the yields in $1 \mathrm{~kg} \mathrm{~B} \mathrm{ha}^{-1}$ applied pots and the control. Rice yield responded to B application due to its positive effect on the number of tillers, panicles, weight of grain and filled grains. These results suggests that B addition improves seed setting due to its major role in many plant physiological functions such as it promotes cell growth and development of the rice panicle (Garg et al., 1979). These findings are consistent with those of Rashid et al. (2002) and Dunn et al. (2005). They found that soil-applied B produced significantly higher yields and up-to $26 \%$ increase has been reported.

Since B is immobile in plants, once utilized in the actively growing tissues, it can not be retranslocated to other tissues. Therefore, it is necessary to have a continuous supply of available B for plant uptake throughout its growth cycle. Boron source PC is a slow release B source as our previous studies on B dissolution kinetics, soil incubation and soil column leaching indicated (Saleem, 2009) so rice plant received adequate B during its growth period. It is apparent from this study that colemanite particle size is very important for B release from fertilizer. The results indicated that PC was as effective as SP in improving all plant growth parameters when used as a B fertilizer. However $\mathrm{GC}$ with its larger particle size ( $0.3 \mathrm{~mm}$ diameter) was less efficient in supplying $\mathrm{B}$ during the growth of the rice plant.

Table 6. Effect of B rates and sources on the rice grain yield per pot

\begin{tabular}{ccccc}
\hline B levels kg ha $^{-1}$ & SP & $\begin{array}{c}\text { PC } \\
\text { grams }\end{array}$ & GC & Mean of B levels \\
\hline 0 & $21.5 \mathrm{~b}$ & $21.5 \mathrm{~b}$ & $21.5 \mathrm{a}$ & $21.5 \mathrm{C}$ \\
1 & $22.1 \mathrm{~b}$ & $22.5 \mathrm{~b}$ & $22.0 \mathrm{a}$ & $22.0 \mathrm{C}$ \\
2 & $25.0 \mathrm{a}$ & $24.0 \mathrm{ab}$ & $23.0 \mathrm{a}$ & $24.0 \mathrm{~B}$ \\
3 & $27.0 \mathrm{a}$ & $26.0 \mathrm{a}$ & $23.5 \mathrm{a}$ & $25.3 \mathrm{~A}$ \\
Mean & $24.1 \mathrm{~A}$ & $23.5 \mathrm{~A}$ & $22 \mathrm{~B}$ & \\
\hline
\end{tabular}

The values with same uppercase letter within columns and rows and the values with same lowercase letter within $\mathrm{B}$ source at different levels are not significantly different at $\mathrm{p}=0.05 . \mathrm{SP}=$ Sodium pentaborate, $\mathrm{PC}=$ Powder Colemanite and $\mathrm{GC}=$ Granular Colemanite.

\section{Conclusion}

The results of this showed strong evidence of the positive effects of SP and PC as a B fertilizer for rice crop. The growth and yield of rice plants depended on the B fertilizer properties especially the particle size. Sodium pentaborate was the most effective B source followed by colemanite in the powder form. In most of the plant parameters studied, the PC was as effective as the SP as a B source. Granular colemanite however was ineffective as a B source over the rice growing period most probably because the amount of B released was inadequate for the rice plant during their growth due to its larger particle size and its low solubility. Colemanite is a cheap source of B so if applied with smaller particle size can give better results by increasing rice crop yield.

\section{Acknowledgement}

The contribution of Agriculture Department Government of Sindh, Pakistan for financial support and University Putra Malaysia for providing all necessary facilities is hereby acknowledged. 


\section{References}

Aslam, M., Mahmood, I. H., Qureshi, R. H., Nawaz, S., \& Akhtar. (2002). Salinity tolerance of rice as affected by boron nutrition. Pakistan Journal of Soil Science, 21, 110-118.

Ashraf, M., Rashid, A., Yasin, M., \& Mann, R. A. (2004). Boron deficiency in calcareous soil reduces rice yield and impairs grain quality. International Rice Research Notes, 29, 58-60.

Benton, J. J. (2001). Laboratory guide for conducting soil tests and plant analysis. CRC Press LLC. USA. $\mathrm{http}: / / \mathrm{dx}$. doi.org/10.1201/9781420025293

Benton, J. J. (2003). Agronomic handbook; management of crops, soils and their fertility. CRC press LLC. USA.

Bell, R. W., \& Dell, B. (2008). Micronutrients for Sustainable Food, Feed, Fibre and bioenergy Production. (1st ed.), IFA, Paris, France.

Bingham, F. T. (1982). Methods of soil analysis, part 2: Chemical and mineralogical properties. In A. L. Boron (Eds.), American Society of Agronomy. pp. 431-448. Madison, WI, USA.

Bolanos, L., Lukaszewski, K., Bonilla, I., \& Blevins, D. (2004). Why boron? Plant Physiology and Biochemistry, 42, 907-912. http://dx.doi.org/10.1016/j.plaphy.2004.11.002

Bremner, J. M., \& Mulvaney, C. S. (1982). Nitrogen-Total. In: Methods of soil analysis. Agron. No. 9, Part 2: Chemical and microbiological properties (2nd ed.). American Society of Agronomy. pp. 595-624. Madison, WI, USA.

Bray, R. H., \& Kurtz, L. T. (1945). Determination of total, organic and available forms of phosphorus. Soil Science, 59, 39-46. http://dx.doi.org/10.1097/00010694-194501000-00006

Byers, D. E., Mikkelsen, R. L., \& Cox, F. R. (2001). Green house evaluation of four boron fertilizer materials. Journal of Plant Nutrition, 24, 717-725. http://dx.doi.org/10.1081/PLN-100103665

Dell, B., Huang, L., \& Bell, R. W. (2002). Boron in plant reproduction. In H. E. Goldbach, B. Rerkasem, M., Wimmer, P. H., Brown, M., Thellier, \& R. W. Bell (Eds.). p. 103 118. Boron in Plant and Animal Nutrition. Kluwer Academic/Plenum Publishers, New York.

Dobbermann, A., \& Fairhurst, T. (2000). Rice. Nutrient disorders \& nutrient management. Handbook series. Potash \& Phosphate Institute (PPI), Potash \& Phosphate Institute of Canada (PPIC) and International Rice Research Institute. p. 191.

Dunn, D., Stevens, G., \& Kending, A. (2005). Boron fertilization of rice with soil and foliar applications. Online Crop Management. http://dx.doi.org/10.1094/CM-2005-0210-01-RS

Ehsan-Ul-Haq M., et al. (2009). Is boron required to improve rice growth and yield in saline environment? Pakistan Journal Botany, 41, 1339-1350.

Garg, O. G., Sharma, A. N., \& Kona, G. R. S. S. (1979). Effect of boron on the pollen vitality and yield of rice plants (Oryza Sativa L. Var. Jaya). Plant and Soil, 52, 591-594. http://dx.doi.org/10.1007/BF02277956

Gee, G. W., \& Bauder, J. W. (1986). Particle size analysis. In Klute, A. (ed). Methods of soil analysis. Part 1. Physical and mineralogical methods. (2nd ed.), pp. 383-411. ASA- SSSA, Wisconsin.

Goldbach, H. E., Yu, Q., Wingender, R., Schulz, M., Wimmer, M., Findeklee, P., \& Baluka, F. (2001). Rapid response reactions of roots to boron deprivation. Journal of Plant Nutrition and Soil Science, 164, 173-181. http://dx.doi.org/10.1002/1522-2624(200104)164:2<173::AID-JPLN173>3.3.CO;2-6

IRRI (International Rice Research Institute). (2008). Background Paper: The rice crisis: What needs to be done? Los Baños (Philippines): IRRI. p.12.

Muhammad Saleem, Mohd Khanif Yusop, Fauziah Ishak, Abd Wahid Samsuri, \& Babar Hafeez (2011). Boron fertilizers borax and colemanite application on rice and their residual effect on the following crop cycle. Soil Science and Plant Nutrition, 57(3), 403-410. http://dx.doi.org/10.1080/00380768.2011.582589

Mohanty, S. (2009). Rice Today, Jan-March 2009 issue, IRRI, Manila Social Sciences Division.

O’Neill, M. A., Ishii, T., Albersheim, P., \& Darvill, A. G. (2004). RhamnogalacturonanII: structure and function of a borate cross-linked cell wall pectic polysaccharide. Annual Review of Plant Biology, 55, 109-139. http://dx.doi.org/10.1146/annurev.arplant.55.031903.141750

Paramananthans, S. (2000). Soils of Malaysia, their Characteristics and Identification. Vol: 1. Academy of Science Malaysia press. 
Rashid, A., Yasin, M., Ali, M. A., Ahmad, Z., \& Ullah, R. (2007). An Alarming Boron Deficiency in Calcareous Rice Soils of Pakistan: Boron Use Improves Yield and Cooking Quality. In F. Xu (Eds.). Advances in Plant and Animal Boron Nutrition, 103-116. http://dx.doi.org/10.1007/978-1-4020-5382-5_9

Rashid, A., Rafique, E., \& Ryan, J. (2002). Establishment and management of boron deficiency in crops in Pakistan: A country report. In H. E. Goldbach (Eds.), Boron in Plant and Animal Nutrition, pp. 339-48. Kluwer Acad. Publication, NewYork. http://dx.doi.org/10.1007/978-1-4615-0607-2_34

Rowell, A. W. G., \& Grant, P. M. (1975). A comparison of fertilizer borate and colemante incorporated in granular fertilizers. Rhod Journal of Agriculture Research, 13, 63-66.

Saleem, M., Khanif, Y. M., Fauziah Ishak, \& Samsuri, A. W. (2009). Dissolution kinetics of boron fertilizers, boron release in soil and effect on rice. Proc, Fourth International Boron Symposium. October, 15-17. Eskisehir-Turkey. pp. 467-471.

Seizo Matsushima. (1980). Easy diagnosis of rice cultivation. pp. 30-31. Rice Cultivation for the Million. Japan scientific societies press.

Shorrocks, V. M. (1997). The occurrence and correction of boron deficiency. Plant and Soil, 193, 121-148. http://dx.doi.org/10.1023/A:1004216126069

Tariq, M., Kakar, K. M., \& Shah, Z. (2005). Effect of boron zinc interaction on the yield, yield attributes and availability of each to wheat (Triticum aestivum L.) grown on calcareous soils. Soil and Environment, 24, 103-108.

Thomas, G. W. (1982). Exchangeable cations. Methods of Soil Analyis. In A. L Page, R. H. Miller, \& D. R. Keeny (Ed.), Part 2, ASA-SSSA. pp. 159-165. Madison WI.

Yan, X., Wu, P., Ling, H., Xu, G., Xu, F., \& Hang, Q. (2006). Plant nutriomics in China: An overview. Annal Botany, 98, 473-482. http://dx.doi.org/10.1093/aob/mcl116

Yang, X., Yu, Y. G., Yang, Y., Bell, R. W., \& Ye, Z. Q. (2000). Residual effectiveness of boron fertilizer for oilseed rape in intensively cropped rice-based rotations. In. Nutrient Cycling in Agro ecosystems, Volume 57, Number 2, p. 171. http://dx.doi.org/10.1023/A:1009837120062

Yu, X., \& Bell, P. F. (2002). Boron and lime effects on yield and deficiency symptoms of rice grown in glasshouse on acid typic glassaqualf. Journal of Plant Nutrition, 25, 2591-2602. http://dx.doi.org/10.1081/PLN-120015524 